\title{
Leptin production in human adipose tissue
}

\author{
Simon W. Coppack ${ }^{1 *}$, Jonathan H. Pinkney ${ }^{2}$ and Vidya Mohamed-Ali ${ }^{1}$ \\ ${ }^{1}$ Department of Medicine, Centre for Weight Management, University College London Medical School, \\ Whittington Campus, Archway Wing, Archway Road, London N19 3UA, UK \\ ${ }^{2}$ University of Bristol Department of Medicine, Bristol Royal Infirmary, Old Building, \\ Marlborough Street, Bristol BS2 8HW, UK
}

Following the initial confirmation of the existence of leptin in humans by Friedman and his colleagues (Zhang et al. 1994), many publications rapidly appeared concerning all aspects of its regulation and action. However, only a small proportion of these have addressed the in vivo physiology of leptin in man. It is apparent that the main determinant of leptin concentrations in both animals and human subjects is whole-body fat mass (Lonnqvist et al. 1995; Maffei et al. 1995; Considine et al. 1996; Bray \& York, 1997). The major target for leptin action in rodents is the hypothalamus (Campfield et al. 1995, 1996; Stephens et al. 1995; Tartaglia et al. 1995). The effects of leptin on the human hypothalamus may be inferred from on-going human clinical trials in which leptin is being administered therapeutically to obese subjects, who have either high leptin concentrations (Amgen Inc., Thousand Oaks, CA, USA), or the very rare leptin deficiency states (Montague et al. 1997a). However, many questions remain unanswered regarding the place of leptin in human energy regulation. These include the manner in which different endocrine and paracrine regulators interact in both the acute and longer-term regulation of leptin production, and the physiological time courses of both the regulation and actions of leptin. Furthermore, the extent to which leptin influences energy balance through actions at peripheral target organs requires further clarification (see Cawthorne et al. 1998).

In the present paper we have focused on the question of the short-term regulation of leptin production in human subjects. Rather than try to cover comprehensively areas of the leptin field that are discussed in detail elsewhere in the present symposium, or in other reviews (Trayhurn, 1996; Bray \& York, 1997; Halaas \& Friedman, 1997), we will seek to focus on: (1) the effect of obesity on leptin production by human adipose tissue; (2) the effect of feeding on leptin production by human adipose tissue; (3) the periodicity of leptin production in human subjects; (4) the effects of sympathomimetic agents on circulating leptin concentrations; (5) the effect of thyroid status on circulating leptin concentrations. Finally, we discuss the possibility that the modulation of the shortterm regulation of leptin may offer therapeutic opportunities in the management of obesity. Before turning to these questions, however, we will first discuss some of the methodological issues concerning the study of human adipose tissue in vivo.

\section{Methods for studying human adipose tissue}

The three principal methods for the study of adipose tissue are ex vivo using biopsy, in vivo by microdialysis (Lonnroth et al. 1987), and in vivo by the Fick principle (Frayn et al. 1989). Since it is relatively straightforward to obtain biopsies of subcutaneous human adipose tissue, many investigators have employed this approach. Quantitative reverse transcription-polymerase chain reaction, in situ and immunocytochemical methods have all been applied to isolated adipocytes and adipose tissue obtained by biopsy to study $o b$ gene expression and leptin secretion in vitro (Lonnqvist et al. 1995; Kolaczynski et al. 1996a,b; Kirschgessner et al. 1997). The microdialysis method has not yet been applied to the study of leptin production, since the leptin molecule will not readily pass through the pores of traditional microdialysis probes. However, the development of probes with larger pore sizes may allow such studies in the future. The Fick principle has been applied to studies of adipose tissue using the method of cannulating superficial abdominal veins, as described by Frayn et al. (1989). Arterio-venous difference measurements are then combined with blood, or plasma, flow measurements usually using the ${ }^{133} \mathrm{Xe}$ washout technique (Larsen et al. 1966). These methods have been critically reviewed previously (Arner \& Bulow, 1993; Frayn et al. 1993; Arner, 1995). Arterio-venous differences across the abdominal adipose tissue have yielded results in close agreement with microdialysis studies (Simonsen et al. 1994). It is very difficult to obtain measurements which quantify the activity of the whole-body fat mass, since adipose tissue is anatomically diffusely distributed throughout the body, and different adipose depots have different metabolic activity (Smith, 1985). Thus, while it may be desirable to extrapolate whole-body adipose tissue activity from studies of small amounts of adipose tissue, this should be done with considerable caution. Previous investigators have rarely been able to correlate the indices of their local measurements with estimates of systemic indices. Although local arterio-venous differences have been shown to correlate with systemic indices of lipolysis (Coppack et al. 1993), some investigators have found negative correlations between systemic and local indices of the same variables (Lillioja et al. 1986; Nordin et al. 1988).

Abbreviations: SNS, sympathetic nervous system; SPSS, Statistical Package for Social Sciences version 6.1; TSH, thyroid-stimulating hormone.

*Corresponding author: Dr S. W. Coppack, fax +44 (0)171 2885302, email scoppack@med.ucl.ac.uk 


\section{Effect of obesity on leptin production by human adipose tissue}

There is a large amount of data confirming that obesity is associated with increased circulating leptin concentrations. Theoretically, this relationship could be due to (a) each given unit of adipose tissue producing a fixed amount of leptin, but there being more tissue, or (b) due to more leptin production per unit adipose tissue, or (c) a combination of both these effects. In obesity, leptin mRNA expression is increased per $\mathrm{g}$ tissue (Lonnqvist et al. 1995), but it is difficult to relate such measurements to protein release by the tissue. Arterio-venous difference methods can measure actual release of protein into the circulation. Using this method, Klein et al. (1996) showed that increased adiposity in men is associated with increased local leptin production rates per $100 \mathrm{~g}$ tissue. We have obtained further data (in collaboration with Dr KN Frayn) which repeat this observation in larger groups of subjects. The mechanism whereby increased adiposity increases leptin production per unit adipose tissue is not clear. Although cell density data were not available for these subjects, in general, obese subjects do not possess more adipocytes per $100 \mathrm{~g}$ adipose tissue. This would imply that individual adipocyte leptin production may increase as the individual cell increases in size. However, mechanisms which might couple adipocyte size to leptin production rates have not yet been delineated.

\section{Effect of feeding on leptin production by human adipose tissue}

Insulin, glucocorticoids and food intake, all of which have satiety effects, have been shown to induce $o b$ gene mRNA expression and to elevate leptin levels (Cusin et al. 1995; De Vos et al. 1995; Trayhurn et al. 1995b). Noradrenaline and neuropeptide $\mathrm{Y}$, which are feeding signals, reduce $o b$ gene expression (Stephens et al. 1995; Trayhurn et al. 1995a). Initial data suggested that leptin gene expression and leptin levels are not acutely regulated by insulin (Kolaczynski et al. $1996 b$ ), ingestion of food or fasting (Boden et al. 1996; Kolaczynski et al. 1996a). However, insulin infusion significantly increased leptin levels after $6 \mathrm{~h}$ (Malstrom et al. 1996). We undertook a study in order (1) to measure leptin production rates per $100 \mathrm{~g}$ adipose tissue, and (2) to compare postprandial leptin concentration and production in response to a high-carbohydrate meal compared with a prolonged fast. The effect of a high-carbohydrate meal on leptin secretion by human subcutaneous adipose tissue was studied, with other subjects acting as time controls during a prolonged fast.

Characteristics of the subjects are shown in Table 1. Body composition was measured by electrical bioimpedance (Bodystat 1500; Bodystat Ltd, Douglas, Isle of Man, UK) or by dual-photon absorptiometry (Lunar Instruments, Madison, WI, USA). Subjects were instructed by a nutritionist on how to maintain a high-carbohydrate diet for $2 \mathrm{~d}$ before the day of study, and subjects completed $3 \mathrm{~d}$ food diaries which were analysed using Dietplan 5 (Forestfield Software Ltd, Horsham, West Sussex, UK).

Fifteen healthy, Caucasian subjects (ten male, five female) were studied in the post-absorptive state (at least $15 \mathrm{~h}$ fasting) and for $5 \mathrm{~h}$ after a high-carbohydrate meal
Table 1. Characteristics of subjects in feeding study

(Median values and interquartile ranges)

\begin{tabular}{|c|c|c|c|c|}
\hline & \multicolumn{2}{|c|}{ Fed subjects } & \multicolumn{2}{|c|}{ Fasting subjects } \\
\hline & Median & $\begin{array}{l}\text { Interquartile } \\
\text { range }\end{array}$ & Median & $\begin{array}{l}\text { Interquartile } \\
\text { range }\end{array}$ \\
\hline$n$ & 15 & & 9 & \\
\hline Male : female & $5: 10$ & & $0: 9$ & \\
\hline Age (years) & $46 \cdot 0$ & $36 \cdot 0-52 \cdot 0$ & $35 \cdot 0$ & $25 \cdot 5-41 \cdot 5$ \\
\hline $\mathrm{BMI}\left(\mathrm{kg} / \mathrm{m}^{2}\right)$ & $38 \cdot 7$ & $31 \cdot 8-46 \cdot 2$ & $23 \cdot 7$ & $20 \cdot 6-36 \cdot 6$ \\
\hline Percentage body fat & $47 \cdot 7$ & $28 \cdot 0-53 \cdot 7$ & $26 \cdot 5$ & $21 \cdot 1-55 \cdot 7$ \\
\hline
\end{tabular}

(energy content adjusted to represent $50 \%$ of BMR; $70 \%$ energy from carbohydrate, $20 \%$ from fat and $10 \%$ from protein). Blood was sampled at baseline (in duplicate) following a $15 \mathrm{~h}$ fast, and at 1,3 and $5 \mathrm{~h}$ after the meal.

Nine Caucasian subjects (all female) acted as time controls for the postprandial study by continuing fasting for periods equivalent to the fed subjects. All subjects gave informed written consent to these studies which had previously been approved by the local Ethics Committee.

Cannulas were inserted, using local anaesthesia, into a radial artery and a superficial epigastric vein draining the subcutaneous abdominal adipose tissue. All lines were kept patent by a slow infusion of isotonic saline $(9 \mathrm{~g} \mathrm{NaCl} / \mathrm{l})$. Blood samples were taken simultaneously from the different sites. Adipose tissue blood flow was determined with ${ }^{133} \mathrm{Xe}$ washout (Larsen et al. 1966) during the baseline sampling and after meals. A tissue : blood coefficient of 10 was assumed for all subjects, as previously advocated (Summers et al. 1996). Other workers have suggested that lower partition coefficients are found in lean subjects (Bulow et al. 1987); using this latter approach would increase the blood flow in obese subjects relative to lean, and strengthen the correlation between adiposity and local leptin production, but would not affect our results for the effects of food. Plasma flow was calculated from blood flow and packed cell volume. The local leptin production by adipose tissue was calculated as the product of arterio-venous difference and local plasma flow (Klein et al. 1996). Leptin was measured using the Linco radioimmunoassay (Biogenesis, Poole, Dorset, UK). The kit has a detection limit of $0.5 \mathrm{ng} / \mathrm{ml}$, with intraand inter-assay $\mathrm{CV}$ of 5.9 and $8.1 \%$ respectively.

The data were analysed using Statistical Package for Social Sciences version 6.1 (SPSS Inc., Chicago, IL, USA; SPSS). Data for age and measures of adiposity are shown as median and interquartile ranges (Table 1). Leptin concentrations at baseline were expressed as the mean of the two samples assayed. In order to analyse trends with time in leptin concentrations and arterio--venous differences, and to reduce population variance, each subject's results at different time points and in venous $v$, arterial blood are expressed with reference to baseline arterial concentration (expressed as $100 \%$ ). Correlation coefficients and ANOVA were used to assess the strength of independent associations between leptin concentrations and the different measures of adiposity. Inter-group comparisons were made with Student's $t$ test for normally-distributed data and Wilcoxon's or Mann-Whitney 
tests for other data. For most data, we have presented the larger groups of fifteen and nine fasted subjects. However, these larger groups were not well-matched for sex so we also carried out subgroup analyses of matched groups of smaller numbers. The conclusions were similar by both methods. Statistical significance was defined as two-tailed, $P<0.05$.

Non-diabetic, Caucasian subjects were studied, representing a wide spectrum of ages, BMI and percentage body fat ranges (median and interquartile range: age $41.5(27 \cdot 0-50.3)$ years, BMI $33.9(23.2-43.7) \mathrm{kg} / \mathrm{m}^{2}$, percentage body fat 46.5 (23.5-51.9)). Diet diaries suggested that subjects increased their carbohydrate intake in the $48 \mathrm{~h}$ before the study from $45.1 \%$ to $56.3 \%$ energy intake, and decreased their fat intake from $30.9 \%$ to $24.9 \%$ energy intake.

In the whole group, leptin concentrations correlated positively and significantly with age, BMI and percentage body fat (Spearman rank correlations; arterial leptin: $v$. age, $r 0.51$ $P<0.001 ; v$. BMI, $r 0.81, P<0.001 ; v$. percentage body fat, $r 0.93, P<0.001$; venous leptin: $v$. age, $r 0.52, P<0.001 ; v$. BMI, $r 0.80, P<0.001 ; v$. percentage body fat, $r 0.91$, $P<0.001)$. After adjustments for age, the correlations of leptin concentrations with both BMI and percentage body fat remained significant. At baseline, leptin production rate per $100 \mathrm{~g}$ tissue correlated with BMI $(r 0.31, P=0.04)$. The female subjects had significantly higher leptin concentrations than the males (ANOVA; $P<0.01$ ), which remained significant after correcting for BMI (ANOVA; $P=0.03$ ), but not after correcting for percentage body fat (ANOVA; $P=0.22$ ). Subcutaneous abdominal adipose tissue leptin production in vivo (median and interquartile range) was 4.7 $(1.0-11.6) \mathrm{ng} / 100 \mathrm{~g}$ adipose tissue per min for the whole group, with women having a significantly higher rate than men $(6.2(1.9-13.6)$ v. $2.4(0.1-7.5) \mathrm{ng} / 100 \mathrm{~g}$ adipose tissue per min respectively; $P=0.024$ ).

In the fifteen subjects studied after a high-carbohydrate meal, leptin concentrations in both arterial and venous samples continued to increase for up to $5 \mathrm{~h}$ (median and interquartile range; baseline $v .5 \mathrm{~h}$ postprandial arterial leptin $31.5(5 \cdot 2-49.7) v .35 \cdot 3(6.5-53.2) \mathrm{ng} / \mathrm{ml}$, NS; baseline v. 5 h postprandial venous leptin $41.2(8 \cdot 3-59.4)$ v. 38.6 (14.1-71.9) ng/ml, $P=0.02$; Table 2 and Fig. 1). Venous concentrations were higher than arterial concentrations at all time points $(P<0.001$ for all $)$.

In the nine fasting subjects studied as time controls, leptin levels fell significantly compared with baseline levels (Table 2 and Fig. 1). Both venous and arterial levels fell significantly during fasting (median and interquartile range; baseline $v .5 \mathrm{~h}$ postprandial arterial $14.2(8.7-47.5) v .9 .8$ $(4.4-41 \cdot 1) \mathrm{ng} / \mathrm{ml}, P=0.008$; venous $19 \cdot 2(14 \cdot 1-60.5)$ v. $12 \cdot 2$ $(6.6-45.3) \mathrm{ng} / \mathrm{ml}, P=0.02$; Table 2 and Fig. 1). Leptin production rates rose with time in the fed subjects but fell in the fasted subjects (Fig. 2). The difference in the percentage change in production rate was significantly different between the two groups at $5 \mathrm{~h}$ (Kruskal-Wallis one-way ANOVA; $P<0.05$ ).

The differences observed between the effects of fasting and feeding were not explained by differences in age and BMI between fed subjects and their time controls. Five of the older and more obese subjects from the fasting study were

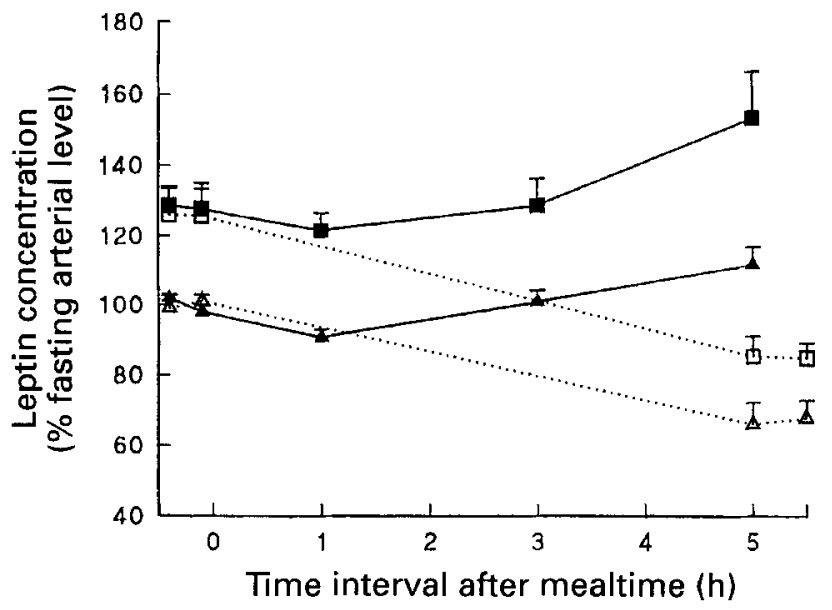

Fig. 1. Concentrations of leptin in fasting and fed subjects. Arterial $(\Delta, \Delta)$ and superficial abdominal venous $(\square, \square)$ concentrations of leptin in fasting $(\Delta, \square)$ and fed $(\Delta, \boldsymbol{\omega})$ subjects, expressed as a percentage of fasting arterial level. For details of subjects and procedures, see Table 1 and p. 462 . Values are means with their standard errors represented by vertical bars.

Table 2. Postprandial and fasting leptin concentrations in fifteen subjects given a high-carbohydrate meal after a $15 \mathrm{~h}$ fast and at 3 and $5 \mathrm{~h}$ after the meal and in nine subjects who fasted throughout the study $\dagger$

(Median values and interquartile ranges)

\begin{tabular}{|c|c|c|c|c|}
\hline & \multicolumn{4}{|c|}{ Leptin concentrations $(\mathrm{ng} / \mathrm{ml})$} \\
\hline & \multicolumn{2}{|c|}{ Fed subjects } & \multicolumn{2}{|c|}{ Fasting subjects } \\
\hline & Median & Interquartile range & Median & Interquartile range \\
\hline \multicolumn{5}{|l|}{ Arterial } \\
\hline $\begin{array}{l}\text { Baseline ( } 15 \mathrm{~h} \text { fast) } \\
3 \mathrm{~h} \text { postprandially ( } 18 \mathrm{~h} \text { fast) } \\
5 \mathrm{~h} \text { postprandially }(20 \mathrm{~h} \text { fast) }\end{array}$ & $\begin{array}{l}31 \cdot 5 \\
30 \cdot 3 \\
35 \cdot 3\end{array}$ & $\begin{array}{l}5 \cdot 2-49 \cdot 7 \\
5 \cdot 2-48 \cdot 9 \\
6 \cdot 5-53 \cdot 2\end{array}$ & $\begin{array}{l}14 \cdot 2 \\
9 \cdot 4^{\star *} \\
9 \cdot 8^{* *}\end{array}$ & $\begin{array}{l}8 \cdot 7-47 \cdot 6 \\
4 \cdot 8-39 \cdot 4 \\
4 \cdot 4-41 \cdot 1\end{array}$ \\
\hline \multicolumn{5}{|l|}{ Venous } \\
\hline $\begin{array}{l}\text { Baseline ( } 15 \mathrm{~h} \text { fast) } \\
3 \mathrm{~h} \text { postprandially }(18 \mathrm{~h} \text { fast) } \\
5 \mathrm{~h} \text { postprandially }(20 \mathrm{~h} \text { fast })\end{array}$ & $\begin{array}{l}41 \cdot 2 \\
37 \cdot 9 \\
38 \cdot 6^{*}\end{array}$ & $\begin{array}{r}8 \cdot 3-59 \cdot 4 \\
9 \cdot 1-64 \cdot 1 \\
14 \cdot 1-71 \cdot 9\end{array}$ & $\begin{array}{l}19 \cdot 2 \\
13 \cdot 5^{*} \\
12 \cdot 2^{*}\end{array}$ & $\begin{array}{r}14 \cdot 1-60 \cdot 5 \\
6 \cdot 4-46 \cdot 1 \\
6 \cdot 6-45 \cdot 3\end{array}$ \\
\hline
\end{tabular}

Median values were significantly different from baseline values: $P<0.05, * * P<0.005$.

For details of subjects and procedures, see Table 1 and p. 462 


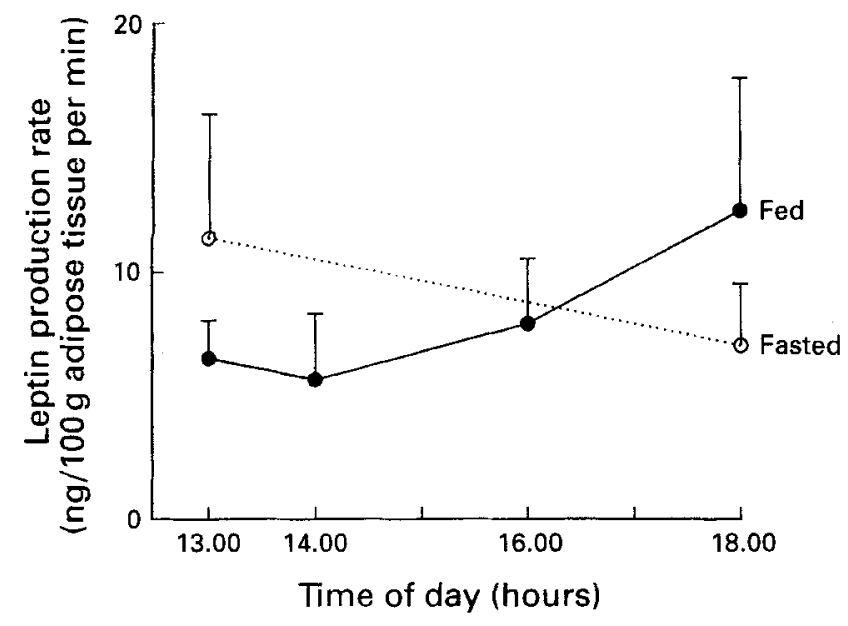

Fig. 2. Leptin production rate in fed $(\bullet)$ and fasting $(0)$ subjects. For details of subjects and procedures, see Table 1 and p. 462. Values are means with their standard errors represented by vertical bars.

matched for sex, age, BMI and percentage body fat to five subjects from the postprandial study, and the same differences were still observed (results not shown).

The effect of feeding and fasting on both plasma concentrations and local release of leptin have been investigated. The results demonstrate in vivo release of leptin by the subcutaneous adipose tissue in the post-absorptive and postprandial states, and also that leptin concentrations and release are higher in females than males. Both leptin concentrations and release, per $100 \mathrm{~g}$ tissue, correlate with measures of adiposity.

Venous leptin concentrations increase $5 \mathrm{~h}$ after a highcarbohydrate meal. The in vivo release increases postprandially but decreases after a prolonged fast, the difference being significant.

Sinha et al. (1996a) investigated leptin plasma concentrations over a $24 \mathrm{~h}$ period and demonstrated a peak at about midnight, but no postprandial effect of food was detected. In contrast to the results of Sinha et al. (1996a), we were able to detect a significant increase in leptin concentration in response to food. The difference in our results may be due to two primary differences in our protocol: subjects' diet and the greater sensitivity of our sampling technique. Our study used epigastric vein cannulation, thus sampling was close to the region of production and, therefore, less prone to dilution effects, whereas all previous studies have utilized mixed venous samples. In the study of Sinha et al. (1996a), subjects were given meals with (\% energy) carbohydrate 50, fat 35 and protein 15, as opposed to carbohydrate 70 , fat 20 and protein 10 in our study. Our subjects, also, were maintained on a high-carbohydrate diet for $48 \mathrm{~h}$ before the study. As has been previously reported, carbohydrates have a higher satiety effect than fat (Lissner \& Heitman, 1995) and, therefore, might be expected to have a more potent effect in stimulating the release of a circulating satiety factor. Further evidence for a differential effect of fat and carbohydrate on leptin response comes from a recent study in which serum leptin concentrations were shown to be significantly related to the percentage change in dietary carbohydrate intake, but not to dietary fat, protein or total energy intake (Jenkins et al. 1997). Our protocol also included a group that continued to fast. The decline in circulating concentrations and local production rate in this group contributed substantially to the difference between fed and fasted groups. Declining concentrations of leptin with increasing duration of fast have been previously recognized (Boden et al. 1996; Kolaczynski et al. 1996a).

The present study examined plasma concentrations and release of leptin separately. While the results confirm several of the previous observations regarding leptin concentration, such as the higher levels in females than in males, the correlation with measures of body fat, and the in vivo release of leptin by human subcutaneous adipose tissue, we now show that local production rates of leptin are higher in females than males. On a per $100 \mathrm{~g}$ subcutaneous adipose tissue basis, women produce nearly 3 -fold more leptin than men, although the differences were not statistically significant when adjusted for total body fat. This may be because men have less subcutaneous fat than women, and subcutaneous fat expresses more leptin mRNA than visceral fat (Montague et al. 1997b). Another explanation for this difference may be the inhibitory effect of testosterone on leptin production (Haffner et al. 1997; Tuominen et al. 1997). In addition, these findings suggest that there is a relatively acute effect of food on leptin production rates. This observation may have gone unnoticed in previous studies based entirely on venous plasma measurements of leptin, whereas the arterio-venous difference technique employed in the present studies is a far more sensitive method for detecting small changes in leptin production.

\section{Pulsatility and periodicity of leptin production}

Many peptide hormones are secreted in a pulsatile fashion, which may have important implications for the inter-tissue signalling subserved by such hormones (Matthews, 1991). To date, two publications have described pulsatility in leptin secretion. Sinha et al. (1996b) studied four lean, eleven obese and five diabetic subjects with mixed venous samples taken every $30-120 \mathrm{~min}$. They identified leptin peaks occurring with a periodicity of 3.25 (SD 0.36$)$ pulses per $24 \mathrm{~h}$ period. The same workers also studied a group of ten fasted obese subjects with samples taken every 15 min overnight. These samples suggested a pulsatile leptin release with 4.20 (SD 0.59 ) pulses during a $12 \mathrm{~h}$ period. Licinio et al. (1997) took samples from six healthy men every $7 \mathrm{~min}$ and identified 32.0 (SD 1.5) pulses per $24 \mathrm{~h}$. However, the conclusions of such analyses are critically dependent on sampling frequency and analytical methods, which may explain the discrepant results.

It might be suggested that pulsatility of a hormone secreted, not from a discrete gland, but rather from a disparate adipose tissue mass, would require a pacemaker mechanism in order to synchronize pulsatility across the entire fat mass. As yet, however, no such pacemaker has been identified, although one might suggest that the sympathetic nervous system is the most likely orchestrator of such a coordinated activity. Another aspect of the periodicity of leptin secretion is that there is a circadian, or diurnal, rhythm 
of leptin concentrations (Sinha et al. 1996a; Schoeller et al. 1997). The functional significance of the leptin diurnal rhythm has not yet been determined, although there is speculation that this might relate to its effectiveness in changing hypothalamic neural activity (Licinio et al. 1997). Likewise, the mechanisms responsible for the peak in leptin concentrations during the early hours of the morning have not been established, although such peaks can be reduced or moved by changing the eating pattern, and/or light-dark, and/or sleep patterns, of subjects (Schoeller et al. 1997).

Although there is no current consensus as to whether leptin release is pulsatile, it is clearly a periodic hormone, and the physiological causes and consequences of this periodicity need further study.

\section{Effect of sympathomimetic agents on circulating leptin concentrations}

Studies in animals (see Trayhum et al. 1998) have shown that sympathetic agonists regulate leptin secretion. Several previous studies have suggested a role for the sympathetic nervous system (SNS) in the acute inhibition of leptin production. Trayhurn et al. (1995a) demonstrated acute inhibitory effects of subcutaneous injections of both isoprenaline and noradrenaline on $o b$ gene expression in murine adipose tissue. In studies on adipocytes and adipocyte cell lines, both noradrenaline and isoprenaline have been shown to reduce $o b$ gene mRNA expression and leptin secretion (Hardie et al. 1996; Kosaki et al. 1996). Furthermore, the selective $\beta-3$ adrenoceptor agonist CL316,243 has been shown to reduce adipose tissue leptin mRNA expression in mice (Gettys et al. 1996). The SNS is the main promoter of lipolysis in man, and insulin the major anti-lipolytic hormone (Hales et al. 1978). In view of the data implicating the SNS in the regulation of leptin, it appears possible that leptin production is coupled to lipolysis. Thus, both leptin production and lipolysis might be regulated by catecholamines, such that fuel mobilization may be coupled to appetite and thermogenesis. Thus, we investigated the effect of isoprenaline infusion on plasma leptin and lipolysis in human subjects.

We examined the effect of intravenous infusions of the non-specific $\beta$-adrenergic agonist isoprenaline on plasma leptin and non-esterified fatty acids in eight healthy fasting volunteers (Pinkney et al. 1998a). In our study, isoprenaline doses were commenced at $0.5 \mu \mathrm{g} / \mathrm{min}$ and titrated upwards, at intervals ranging from 15 to $60 \mathrm{~min}$ in order to give a steady-state biological response in all subjects (heart rate $>100$ beats/min but $<$ twice pre-infusion heart rate). Once steady heart-rate responses were achieved, the infusion rates were not further adjusted. Target heart rates were achieved in all subjects. Isoprenaline infusion rates achieving the desired biological response were (median and range) $2.0(1.5-3.0) \mu \mathrm{g} / \mathrm{min}$. Pre-infusion blood samples were taken at baseline, and then every $15 \mathrm{~min}$ during $3 \mathrm{~h}$ infusion of isoprenaline, and every $15 \mathrm{~min}$ for $1 \mathrm{~h}$ during the post-infusion recovery phase. Using this protocol, the isoprenaline infusion rate required to achieve the biological end point was (median and interquartile range) $2.0(2.0-2.5)$ $\mu \mathrm{g} / \mathrm{min}$, with the infusion maintained for $180 \mathrm{~min}$. Statistical analyses were performed using SPSS. Between-time point

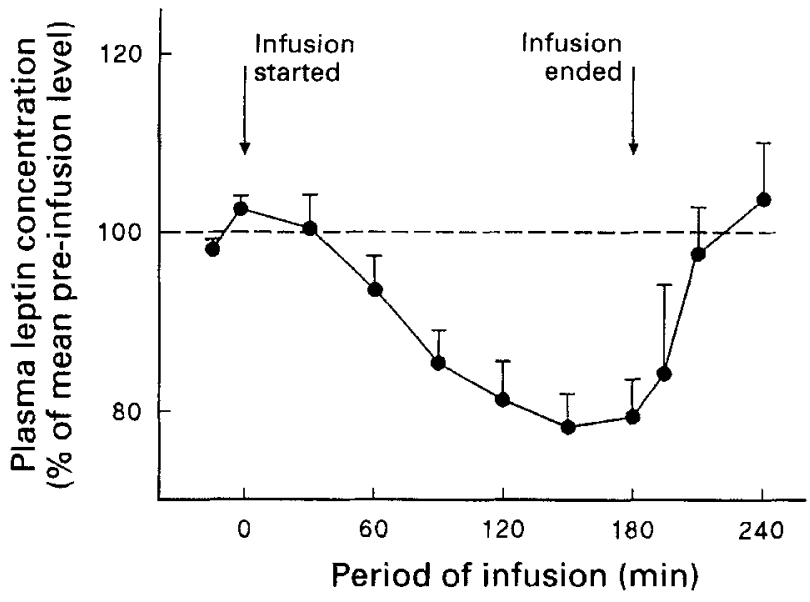

Fig. 3. Effect of isoprenaline infusion on plasma leptin concentrations in healthy subjects. (- ), Mean baseline values. For details of subjects and procedures, see p. 465 . Values are means with their standard errors represented by vertical bars.

comparisons were performed with Wilcoxon's test. Significance was defined as two-tailed, $P<0.05$.

The baseline pre-infusion plasma leptin concentration was (median and interquartile range) $6.3(3 \cdot 0-12 \cdot 8) \mathrm{ng} / \mathrm{ml}$. Plasma leptin responses to the infusion of isoprenaline are shown in Fig. 3. Compared with baseline, leptin concentrations were unchanged up to $60 \mathrm{~min}$. Plasma leptin began to decrease significantly after $90 \mathrm{~min}(P<0.05)$. Thereafter, plasma leptin concentrations decreased significantly in all subjects, with maximum suppression by $120 \mathrm{~min}$, and levels remained suppressed until the isoprenaline infusion was discontinued $(P<0.0005)$. Leptin concentrations (median and interquartile range) were suppressed to $81.3(76.5-87.3) \%$ of baseline at $t 120 \mathrm{~min}(P<0.02)$ and recovered to 95.3 $(91.5-114.9) \%$ at the end of the recovery period $(t 120 \mathrm{~min}$ $v$. end of recovery, $P=0.05$, baseline recovery, $P=0.05$; baseline $v$. end of recovery, NS). After discontinuation of isoprenaline at $180 \mathrm{~min}$, leptin concentrations very rapidly increased, and were already higher after $15 \mathrm{~min}$ of recovery $(P<0.05$; Fig. 3).

These results demonstrate that intravenous infusion of the $\beta$-adrenergic agonist isoprenaline in human subjects causes a fall in circulating plasma leptin concentrations within $3 \mathrm{~h}$, and an increase within $15 \mathrm{~min}$ of discontinuation of isoprenaline infusion. It is likely that isoprenaline effects on leptin are mediated by $\beta$-adrenergic receptors on adipocytes. Other studies have suggested that leptin secretion responds to $\beta$-adrenergic agonists, but the speed of the responses seen in our study, and in the study of Donahoo et al. (1997), was unexpected.

The changes in plasma leptin levels were accompanied by concomitant increases in plasma concentrations of nonesterified fatty acids and insulin. Both heart rate and systolic blood pressure increased significantly during isoprenaline infusion, and declined abruptly during the post-infusion recovery phase.

The rate of the suppression of plasma leptin concentrations was a function of both our infusion protocol, which slowly titrated the isoprenaline dose (to minimize the risk 
of dose-related cardiovascular side effects), and of the physiological delay in the action of the compound. Even so, significant falls in leptin concentrations were apparent within $1.5-2 \cdot 0 \mathrm{~h}$ of the start of isoprenaline infusion. However, the very rapid increase (within $15 \mathrm{~min}$ ) in leptin concentrations after isoprenaline was discontinued suggests the effect of $\beta$-adrenergic-mediated inhibition of leptin production may be even more acute. In a previous report, plasma leptin in obese, but not lean, human subjects was observed to fall in response to a mental stress test, although clonidine had no effect on plasma leptin levels (Del Rio et al. 1997).

It has long been recognized that the SNS and insulin coregulate lipolysis (and consequently plasma non-esterified fatty acids, thermogenesis and body weight; Eckel et al. 1996). The isoprenaline infusion data add to the recognition that leptin may be an integral part of these control mechanisms. In addition to the direct induction of non-esterified fatty acids by the SNS, in vitro studies on rat adipocytes have shown that leptin impairs insulin inhibition of isoprenalineinduced lipolysis, contributing to the overall lipolytic effect (Muller et al. 1997). Thus, it may be suggested that leptin could mediate aspects of the stress response affecting appetite and adipose mass regulation. If acute SNS activation is considered both to suppress leptin production and increase lipolysis, then appetite would be stimulated, replenishing fuel stores, and the sympathetic-induced increase in thermogenesis would be reduced towards a notional set-point. Also, the evidence for sympathetic responsiveness suggests that circulating leptin concentrations may signal not only a measure of adipose tissue mass, which may change from weekto-week, but also represent a far more dynamic acute indicator of the prevailing direction of the lipolytic-lipogenic equilibrium in adipose tissue. The SNS in its effects on adipose tissue has not been regarded traditionally as a classical endocrine loop with feedback inhibition. However, the observation that leptin is acutely regulated by sympathetic stimulation supports the view that leptin may also operate as a counter-regulator for SNS activity in adipose tissue (Mantzoros et al. 1996).

It may be suggested that inter-individual differences in the sensitivity of adipocytes to $\beta$-adrenergic regulation of leptin and lipolysis might lead to differences in the accumulation of adipose tissue. Evidence for impaired adrenergic responsiveness of lipolysis in obese subjects has emerged already (Reynisdottir et al. 1994; Bougneres et al. 1997), although it is still not completely clear whether these changes are primary or secondary to obesity. Thus, it will be intriguing to see whether increasing adiposity is also accompanied by impairment of the acute adrenergic regulation of leptin.

\section{Effect of thyroid status on circulating leptin concentrations}

The pituitary-thyroid axis, acting in conjunction with the SNS, plays a central role in the regulation of adipose tissue metabolism (Oppenheimer et al. 1991; Saffari et al. 1992; Wahrenburg et al. 1994; Blennmann et al. 1995). In the fasted or malnourished state, the secretion of thyroidstimulating hormone (TSH) and thyroxine declines, leading to reduced energy expenditure. In contrast, in obese 'euthyroid' subjects TSH levels are at the higher end of the 'normal' range. Leptin secretion also declines with fasting and increases with feeding (see pp. 462-464), showing that leptin production and pituitary-thyroid axis activity may respond concomitantly with nutritional status.

However, it remains controversial whether leptin and the pituitary-thyroid axis interact, or whether dysregulation of leptin contributes to energy imbalance in dysthyroid states. The existing human data on the relationship between the pituitary-thyroid axis and leptin are conflicting. In one cross-sectional study no alterations in plasma leptin levels were observed in patients with primary thyroid disease (Sreenan et al. 1997), whilst in two other studies plasma leptin was elevated in hyperthyroid subjects (Valcavi et al. 1997; Yoon et al. 1997). In contrast, our preliminary studies (see pp. 466-467) have shown markedly elevated plasma leptin in hypothyroid patients and low levels in hyperthyroid patients (Pinkney et al. 1998b). In addition to these conflicting clinical data, in vitro studies exploring the influence of triiodothyronine on leptin mRNA expression in adipocytes have also arrived at conflicting conclusions (Fain et al. 1997; Yoshida et al. 1997). However, in further support of an inverse relationship between these axes, thyroidectomized rodents have increased serum leptin levels, and thyroid hormone treatment reduces these levels (Escobar-Morreale et al. 1997; also see Trayhurn et al. 1998).

In preliminary studies we have investigated eighteen hypothyroid patients (Pinkney et al. 1998b) identified with newly-diagnosed untreated primary hypothyroidism over a 6-month period. New patients were identified through NHS Clinical Biochemistry laboratories, Bristol, and studied before the initiation of treatment. All patients were systematically examined, and symptoms and signs of thyroid disease were confirmed by a single observer (JHP). All patients had unequivocal symptoms and signs of thyroid disease. Subjects with hypothalamic-pituitary disease or sick euthyroid syndrome were excluded. Physical signs confirming thyroid dysfunction included facial appearance, heart rate and rhythm, and texture of skin and hair. Sixty-five clinicallyand biochemically-euthyroid control subjects were identified from among departmental staff $(n 30)$ and from a weightmanagement clinic ( $n 35)$. Subjects were all non-diabetic and biochemically-euthyroid. Informed consent was obtained from patients and their primary care physicians, and from control subjects.

Subjects attended in the fasting state. Percentage body fat was measured by electrical bioimpedance (Bodystat 1500; Bodystat Ltd). Patients with hypothyroidism were treated with thyroxine, initiated at $50 \mu \mathrm{g}$ daily. Further dose adjustments were managed by primary care physicians. Follow-up measurements of thyroid function and plasma leptin were obtained after a mean interval of 7 (range 3-9) months in eleven patients with hypothyroidism. Fasting plasma leptin concentrations were measured (Goodrick et al. 1996) as well as free triiodothyronine, free thyroxine and TSH (chemiluminescent immunometric assays; Ciba-Corning, Halstead, Essex, UK). Statistical analysis was performed using SPSS. Leptin concentrations in lean and obese euthyroid subjects, and hypothyroid patients were compared cross-sectionally by Mann-Whitney U test. In hypothyroid patients the effects 
of thyroxine on plasma leptin concentrations were analysed by Wilcoxon's test. Significance was defined as two-tailed, $P<0.005$.

The hypothyroid patients had similar body composition (BMI, waist : hip ratio, percentage body fat) to the lean euthyroid subjects and both these groups were significantly less obese than the obese euthyroid group. Untreated hypothyroid patients had similar leptin levels (median and interquartile range; $19.21(5 \cdot 1-98.98) \mathrm{ng} / \mathrm{ml})$ to those of obese euthyroid subjects $(31.48(5 \cdot 15-103.80) \mathrm{ng} / \mathrm{ml}$; NS) and both these groups had higher leptin levels than those of lean euthyroid subjects $(6.61(1.11-28.41) \mathrm{ng} / \mathrm{ml} ; P<0.0001)$.

Eleven hypothyroid subjects were followed up after treatment. After a median period of 7 months, plasma leptin concentrations in the hypothyroid group had fallen (median and interquartile range; from $19.21(11.46-31.52)$ to 15.31 $(5.78-23.71) \mathrm{ng} / \mathrm{ml}$ at follow-up; $P=0.03)$. At follow-up, mean plasma leptin concentrations of hypothyroid patients were no longer significantly different from values for a group of age- and weight-matched controls (selected from euthyroid group). The changes in plasma leptin concentrations resulting from treatment of hypothyroidism were accompanied by the expected alterations in concentrations of TSH in the hypothyroid group (median and range; pretreatment 43.0 $(18-50.0) \mathrm{mIU} / \mathrm{l} v$. post-treatment $2.2(0.05-17.0) \mathrm{mIU} / \mathrm{l}$; Wilcoxon's test $P=0 \cdot 02$ ).

These findings suggest that the activity of the pituitary-thyroid axis is related to plasma leptin levels, and raise the interesting possibility of a functional link between these two endocrine axes. In a well-characterized population of patients with clinically- and biochemically-confirmed thyroid dysfunction, we have observed relative hyperleptinaemia in hypothyroid patients. Thus, hypothyroid patients had leptin levels similar to those of obese subjects. These differences were not explained by differences in BMI, waist : hip ratio or percentage body fat. Furthermore, in hypothyroid patients leptin concentrations changed in response to thyroxine treatment. These findings contrast with some recent studies which have found no change in plasma leptin in thyroid patients (Sreenan et al. 1997; Valcavi et al. 1997).

It is possible that there may have been differences in patient populations between these studies, such as lesshomogeneous groups of dysthyroid subjects, some of whom may have been partially treated. Furthermore, the studies have used different leptin assays and this may also contribute to some degree to the varying results. Our results seem to agree better with the results of Fain et al. (1997) and Escobar-Morreale et al. (1997). Fain et al. (1997) observed increased leptin mRNA expression hypothyroid rats, and a reduction in expression in response to triiodothyronine treatment, while Escobar-Morreale et al. (1997) made similar observations on rats in vivo. Thus, the present findings, in human subjects, support an inverse relationship between thyroid activity and leptin production within adipose tissue, although the precise time course of this effect cannot be determined from these data.

Based on the previously mentioned findings, it might be postulated that triiodothyronine-induced alterations in adipocyte sensitivity to catecholamines could explain how thyroid dysfunction gives rise to altered plasma leptin concentrations. Thus, the results of the study of hypothyroid subjects may be interpreted in the context of adipocyte $\beta$ adrenoceptor sensitivity. Our results support the hypothesis that leptin, the SNS and the pituitary-thyroid axis might represent interacting systems for energy homeostasis (Legradi et al. 1997). In hypothyroid patients, leptin concentrations were reversibly elevated, compatible with a direct effect of the hypothyroid state on leptin production at the level of the adipocyte.

\section{Summary and avenues for further research}

Studies of leptin production in human adipose tissue suggest that its regulation is similar to that observed in animals. The principal conclusions of the work discussed in the present contribution may be summarized as follows.

(1) Leptin production in human subjects, per unit mass of adipose tissue, increases with increasing obesity, suggesting a qualitative defect in leptin regulation in obesity.

(2) Leptin production increases within $5 \mathrm{~h}$ of eating a meal; the superior sensitivity of the arterio-venous difference technique demonstrates a more acute effect of feeding on leptin production than was apparent from studies on venous plasma.

(3) Leptin secretion exhibits a circadian rhythm with nighttime peaks, but the factors entraining this rhythm are unclear. The evidence for pulsatile release is inconclusive.

(4) Leptin concentrations respond swiftly to isoprenaline infusion, in support of a role for the SNS in the acute regulation of leptin.

(5) Leptin levels are increased in hypothyroidism, but return to normal during treatment with thyroxine. The effects of thyroxine and $\beta$-adrenergic agonists on plasma leptin could be consistent with dual thyroid-sympathetic negative regulation of leptin.

The picture that emerges from such human studies is that, although the size of the adipose tissue mass is the dominant determinant of long-term leptin concentrations, it is certainly not the only one. Our data suggest that thyroid status is also a significant regulator of leptin, over a time course of perhaps a few weeks. There are also important short-term regulators of leptin production, such as time of day, eating pattern, and the SNS. Other significant regulators undoubtedly include glucocorticoids and cytokines, but are beyond the scope of the present contribution.

The existence of these multiple mechanisms regulating leptin raises the question whether the modulation of such mechanisms might offer therapeutic possibilities in the treatment of obesity. It is already clear that human obesity is not due to major disruption of adipose tissue leptin production, or target organ signalling, in the vast majority of subjects. Thus, human obesity is clearly different from that in genetically-obese strains of mice. In general, leptin concentrations fall as obese human subjects lose weight (Maffei $e t$ al. 1995; Rosenbaum et al. 1997), suggesting the production of leptin is appropriate for the whole-body adipose tissue mass. There may be, however, more subtle abnormalities of 
leptin secretion in some obese subjects (e.g. relative leptin deficiency for the degree of existent obesity; Ravussin et al. 1997). Whether or not leptin dysregulation plays any primary role in the development of human obesity, its presence may nevertheless preserve obesity. The decline in leptin concentrations that occurs during net negative energy balance almost certainly reduces metabolic rate and increases hunger, and these effects may contribute to the failure of many obese individuals to respond to voluntary dietary measures. In this way, the augmentation of leptin concentrations, or of leptin signalling, may still be useful approaches to the treatment of obesity.

In conclusion, a detailed understanding of the acute regulation of leptin in human subjects might allow the design of diets and patterns of eating that do not adversely reduce leptin concentrations. Manipulation of leptin production through other short-term regulatory pathways, including the SNS, may also offer new ways to counter the onset of mechanisms which resist further weight loss.

\section{Acknowledgements}

We gratefully acknowledge the support of the British Heart Foundation (PG/95145), The Wellcome Trust, and the Research Foundation of Southmead Hospital, Bristol.

\section{References}

Arner P (1995) Techniques for the measurement of white adipose tissue metabolism. International Journal of Obesity 19, 435-442.

Arner P \& Bulow J (1993) Assessment of adipose tissue metabolism in man. Clinical Science 85, 247-256.

Blennemann B, Leahy P, Kim TS \& Freake HC (1995) Tissue specific regulation of lipogenic mRNAs by thyroid hormone. Molecular and Cellular Endocrinology 110, 1-8.

Boden G, Chen X, Mozzoli M \& Ryan I (1996) Effect of fasting on serum leptin in normal human subjects. Journal of Clinical Endocrinology and Metabolism 81, 3419-3423.

Bougneres P, Le Stunff C, Pecqeuer C, Pinghlier E, Adnot P \& Ricquier D (1997) In vivo resistance of lipolysis to epinephrine. A new feature of childhood obesity. Journal of Clinical Investigation 99, 2568-2573.

Bray GA \& York DA (1997) Leptin and clinical medicine: a new piece in the puzzle of obesity. Journal of Clinical Endocrinology and Metabolism 82, 2771-2776.

Campfield LA, Smith FJ \& Burn P (1996) The OB protein (leptin) pathway - a link between adipose tissue mass and central neural networks. Hormone and Metabolic Research 28, 619-632.

Campfield LA, Smith FJ, Guisez Y, Devos R \& Burn P (1995) Recombinant mouse $O B$ protein: evidence for a peripheral signal linking adiposity and central neural networks. Science 269 , 546-549.

Cawthorne MA, Morton NM, Pallett AL, Liu Y-L \& Emilsson V (1998) Peripheral metabolic actions of leptin. Proceedings of the Nutrition Society 57, 449-453.

Considine RV, Sinha MK, Heiman ML, Kriauciunas A, Stephens TW, Nyce MR, Ohamessian JP, Marco CC, McKee LJ, Bauer TK \& Caro JF (1996) Serum immunoreactive-leptin concentrations in normal-weight and obese humans. New England Journal of Medicine 334, 292-295.

Coppack SW, Judd RL \& Miles JM (1993) Uptake and release of glycerol and free fatty acids by human adipose and muscle tissues in vivo. Diabetes 42, Suppl. 1, 38A Abstr.
Cusin I, Sainsbury A, Doyle P, Rohmer-Jeanrenaud F \& Jeanrenaud $B$ (1995) The ob gene and insulin: a relationship leading to clues to the understanding of obesity. Diabetes 44, 1467-1470.

Del Rio G, Menozzi R, Bertolini M, Venneri MG, Tavernari V, Valeriani L, Bondi M \& Velardo A (1997) Relationship between sympathoadrenal system and plasma leptin levels in normal and obese subjects. International Journal of Obesity 21, Suppl. 2, 343 Abstr.

De Vos P, Saladin R, Auwerx J \& Staels B (1995) Induction of ob gene expression by corticosteroids is accompanied by body weight loss and reduced food intake. Journal of Biological Chemistry 270, 15958-15961.

Donahoo WT, Jensen DR, Yost TJ \& Eckel RH (1997) Isoproterenol and somatostatin decrease plasma leptin in humans: a novel mechanism regulating leptin secretion. Journal of Clinical Endocrinology and Metabolism 82, 4139--4143.

Eckel RH, Jensen DR, Schlaepfer IR \& Yost TJ (1996) Tissuespecific regulation of lipoprotein lipase by isoprenaline in normal-weight humans. American Journal of Physiology 271, R1280-R1286.

Escobar-Morreale HF, Escobar del Rey F \& Morreale de Escobar G (1997) Thyroid hormone influences serum leptin concentrations in the rat. Endocrinology 138, 4485-4488.

Fain JN, Coronel EC, Beauchamp MJ \& Bahouth SW (1997) Expression of leptin and beta 3 -adrenergic receptors in rat adipose tissue in altered thyroid states. Biochemical Journal 322, $145-150$.

Frayn KN, Coppack SW \& Humphreys SM (1993) Subcutaneous adipose tissue metabolism studied by local catheterisation. International Journal of Obesity 17, Suppl. 3, S18-S21.

Frayn KN, Coppack SW, Humphreys SM \& Whyte PL (1989) Metabolic characteristics of human adipose tissue in vivo. Clinical Science 76, 509-516.

Gettys TW, Harkness PJ \& Watson PM (1996) The beta 3-adrenergic receptor inhibits insulin-stimulated leptin secretion from isolated rat adipocytes. Endocrinology 137, 4054-4057.

Goodrick SJ, Mohamed-Ali V, Jowett T, O'Shea A, Yudkin JS \& Coppack SW (1996) A two site monoclonal immunoradiometric assay for human leptin. Diabetologia 39, A142 Abstr.

Haffner SM, Miettinen H, Karhappa P, Mykkanen L \& Laakso M (1997) Leptin concentrations, sex hormones, and cortisol in nondiabetic men. Journal of Clinical Endocrinology and Metabolism 82, 1807-1809.

Halaas JL \& Friedman JM (1997) Obesity and the adipocyte: leptin and its receptor. Journal of Endocrinology 155, 215-216.

Hales CN, Luzio JP \& Siddle K (1978) Hormonal control of adipose tissue lipolysis. Biochemical Society Symposium 43, 97-135.

Hardie LJ, Guilhot N \& Trayhurn P (1996) Regulation of leptin production in cultured mature white adipocytes. Hormone and Metabolism Research 28, 685-689.

Jenkins AB, Markovic TP, Fleury A \& Campbell LV (1997) Carbohydrate intake and short-term regulation of leptin in humans. Diabetologia 40, 348-351.

Kirschgessner TG, Uysai KT, Weisbrock SM, Marino MW \& Hotamisligil GS (1997) Tumor necrosis factor-alpha contributes to obesity-related hyperleptinemia by regulating leptin release from adipocytes. Journal of Clinical Investigation 100, 2777-2782.

Klein S, Coppack SW, Mohamed-Ali V \& Landt M (1996) Adipose tissue leptin production and plasma leptin kinetics in humans. Diabetes 45, 984-987.

Kolaczynski JW, Considine RV, Ohannesian JP, Marco CC, Opentanova I, Nyce MR, Myint M \& Caro JF (1996a) Response of leptin to short-term fasting and refeeding in humans. Diabetes 45, 1511-1515.

Kolaczynski JW, Nyce MR, Considine RV, Boden G, Nolan JJ, Henry R, Mudaliar SR, Olefsky J \& Caro JF (1996b) Acute and 
chronic effects of insulin on leptin production in humans. Diabetes 45, 699-701.

Kosaki A, Yamada K \& Kuzuya H (1996) Reduced expression of the leptin gene (ob) by catecholamine through a Gs proteincoupled pathway in 3T3-L1 adipocytes. Diabetes $\mathbf{4 5}$, 1744-1749.

Larsen OA, Lassen NA \& Quaade F (1966) Blood flow through human adipose tissue determined with radioactive xenon. Acta Physiologica Scandinavica 66, 337-345.

Legradi G, Emerson CH, Ahima RS, Flier JS \& Lechan RM (1997) Leptin prevents fasting-induced suppression of prothyrotropinreleasing hormone messenger ribonucleic acid in neurons of the hypothalamic paraventricular nucleus. Endocrinology 138, 2569-2576.

Licinio J, Mantzoros C, Negrao AB, Cizza G, Wong M-L, Bongiorno P-B, Chrousos GP, Karp B, Allen C, Flier JS \& Gold PW (1997) Human leptin levels are pulsatile and inversely related to pituitary-adrenal function. Nature Medicine $\mathbf{3}$, 575-579.

Lillioja S, Foley JE, Bogardus C, Mott DM \& Howard BV (1986) Free fatty acid metabolism and obesity in man: in vivo comparisons. Metabolism 35, 505-514.

Lissner L \& Heitman BL (1995) The dietary fat : carbohydrate ratio in relation to body weight. Current Opinion in Lipidology 6 , 8-13.

Lonnqvist F, Amer P, Nordfors L \& Schalling M (1995) Overexpression of the obese (ob) gene in adipose tissue in human obese subjects. Nature Medicine 1, 950-953.

Lonnroth P, Jansson P-AE \& Smith U (1987) A microdialysis method allowing characterisation of intercellular water space in humans. American Journal of Physiology 253, E228-E231.

Maffei M, Halaas J, Ravussin E, Pratley RE, Lee GH, Zhang Y, Fei H, Kim S, Lallone R, Ranganathan S, Kern PA \& Friedman JM (1995) Leptin levels in human and rodent: measurement of plasma leptin and ob RNA in obese and weight reduced subjects. Nature Medicine 1, 1155-1161.

Malstrom R, Taskinen M-R, Karonen S-L \& Yki-Jarvinen H (1996) Insulin increases plasma leptin concentrations in normal subjects and patients with NIDDM. Diabetologia 39, 993-996.

Mantzoros CR, Qu D, Frederich RC, Susulic VS, Lowell BB, Maratos-Flier E \& Flier JS (1996) Activation of beta 3-adrenergic receptors suppresses leptin expression and mediates a leptin independent inhibition of food intake in mice. Diabetes 45, 909-914.

Matthews DR (1991) Physiological implications of pulsatile hormonal secretion. Annals of the New York Academy of Sciences 618, 28-37.

Montague CT, Farooqi IS, Whitehead JP, Soos MA, Rau H, Wareham NJ, Sewter CP, Digby JE, Mohammed SN, Hurst JA, Cheetham CH, Earley AR, Barnett AH, Prins JB \& O'Rahilly S (1997a) Congenital leptin deficiency is associated with severe early-onset obesity in humans. Nature 387, 903-908.

Montague CT, Prins JB, Sanders L, Digby JE \& O'Rahilly S (1997b) Depot- and sex-specific differences in human leptin mRNA expression. Diabetes 46, 342-347.

Muller G, Ertl J, Gerl M \& Preibisch G (1997) Leptin impairs metabolic actions of insulin in isolated rat adipocytes. Journal of Biological Chemistry 272, 10585-10593.

Nordin G, Agarth CD, Hansson P \& Nilsson-Ehle P (1988) Triglyceride-glycerol synthesis in fat cells during lactation. In Obesity in Europe [P Bjorntorp and S Rossner, editors]. London: John Libbey.

Oppenheimer JH, Schwartz HL, Lane TJ \& Thompson MP (1991) Functional relationship of thyroid hormone-induced lipogenesis, lipolysis and thermogenesis in the rat. Journal of Clinical Investigation $87,125-132$.

Pinkney JH, Coppack SW \& Mohamed-Ali V (1998) Effect of isoprenaline on plasma leptin and lipolysis in humans. Clinical Endocrinology 48, 407-412.

Pinkney JH, Goodrick SJ, Katz JR, Johnson AB, Lightman SL, Coppack SW \& Mohamed-Ali V (1998) Leptin and the pituitarythyroid axis : a comparative study in lean, obese, and hypothyroid and hyperthyroid subjects. Clinical Endocrinology (In the Press).

Ravussin E, Pratley RE, Maffei M, Wang H, Friedman JM, Bennett PH \& Bogardus C (1997) Relatively low plasma leptin concentrations precede weight gain in Pima Indians. Nature Medicine 3 , 238-240.

Reynisdottir S, Wahrenburg H, Carlstrom K, Rossner S \& Arner P (1994) Catecholamine-resistance in fat cells of upper body obese women due to decreased expression of beta $a_{2}$-adrenoceptors. Diabetologia 37, 428-435.

Rosenbaum M, Nicolson M, Hirsch J, Murphy E, Chu F \& Leibel RL (1997) Effects of weight change on plasma leptin concentrations and energy expenditure. Journal of Clinical Endocrinology and Metabolism 82, 3647-3654.

Saffari B, Ong JM \& Kern PA (1992) Regulation of adipose tissue lipoprotein lipase gene expression by thyroid hormone in rats. Journal of Lipid Research 33, 241-249.

Schoeller DA, Cella LK, Sinha MK \& Caro JF (1997) Entrainment of the diumal rhythm of plasma leptin to meal timing. Journal of Clinical Investigation 100, 1882-1887.

Simonsen L, Bulow J \& Madsen J (1994) Adipose tissue metabolism in humans determined by vein catheterisation and microdialysis techniques. American Journal of Physiology 266, E357-E365.

Sinha MK, Ohannesian JP, Heiman ML, Kriauciunas A, Stephens TW, Magosin S, Marco CC \& Caro JF (1996a) Nocturnal rise in leptin in lean, obese, and non-insulin-dependent diabetes mellitus subjects. Journal of Clinical Investigation 97, 1344-1347.

Sinha MK, Sturis J, Ohannesian H, Magosin S, Stephens T, Heiman ML, Polonsky KS \& Caro JF (1996b) Ultradien oscillations of leptin in humans. Biochemical and Biophysical Research Communications 228, 733-738.

Smith U (1985) Regional differences in adipocyte metabolism and possible consequences in vivo. International Journal of Obesity 9, 145-148.

Sreenan S, Caro JF \& Refetoff S (1997) Thyroid dysfunction is not associated with alterations in serum leptin levels. Thyroid 7 , 407-409.

Stephens TW, Basinski M, Bristow PK, Bue-Valleskey JW, Burgett SG, Craft L, Hale J, Hoffman J, Hsiung HM, Kriauciunas A, MacKeller W, Rosteck PR Jr, Schoner B, Smith D, Tinsley FC, Zhang X-Y \& Heiman M (1995) The role of neuropeptide Y in the anti-obesity action of the obese gene product. Nature 377 , 530-532.

Summers LKM, Samra JS, Humphreys SM, Morris RJ \& Frayn KN (1996) Subcutaneous adipose tissue blood flow : variation within and between subjects and relationship to obesity. Clinical Science 91, 679-683.

Tartaglia LA, Dembski M, Weng X, Deng N, Culpepper J, De Vos R, Richards JG, Campfield LA, Clark FT, Deeds J, Muir C, Sanker S, Moriarty A, Moore KJ, Smutko JS, Mays GG, Woolf EA, Monroe CA \& Tepper RI (1995) Identification and expression cloning of a leptin receptor, OB-R. Cell 83, 1263-1271.

Trayhurn P (1996) New insights into the development of obesity, obesity genes and the leptin system. Proceedings of the Nutrition Society 55, 783-791.

Trayhurn P, Duncan JS, Hoggard N \& Rayner DV (1998) Regulation of leptin production: a dominant role for the sympathetic 
nervous system. Proceedings of the Nutrition Society 57, 413-419.

Trayhurn P, Duncan JS \& Rayner DV (1995a) Acute cold induced suppression of $o b$ (obese) gene expression in white adipose tissue of mice: mediation by the sympathetic system. Biochemical Journal 311, 729-733.

Trayhurn P, Thomas ME, Duncan JS \& Rayner DV (1995b) Effects of fasting and refeeding on $o b$ gene expression in white adipose tissue of lean and obese $(o b / o b)$ mice. FEBS Letters 368, $488-490$.

Tuominen JA, Ebeling P, Stenman UH, Heiman ML, Stephens TW \& Koivisto VA (1997) Leptin synthesis is resistant to acute effects of insulin in insulin-dependent diabetes mellitus patients. Journal of Clinical Endocrinology and Metabolism 82 , 381-382.

Valcavi R, Zini M, Peino R, Casanueva FF \& Dieguez C (1997) Influence of thyroid status on serum immunoreactive leptin levels. Journal of Clinical Endocrinology and Metabolism 82, 1632-1634.

Wahrenburg H, Wenlund A \& Arner P (1994) Adrenergic regulation of lipolysis in fat cells from hyperthyroid and hypothyroid patients. Journal of Clinical Endocrinology and Metabolism 78, 898-903.

Yoon DJ, Frank GR, Lacanilao R, Kreitzer P \& Carey DE (1997) Effect of thyroid hormone on serum leptin levels: A positive correlation in girls with thyroid disorders. Endocrinology P2-8, 286 Abstr.

Yoshida T, Monkawa T, Hayashi M \& Saruta T (1997) Regulation of expression of leptin mRNA and secretion of leptin by thyroid hormone in 3T3-L1 adipocytes. Biochemical and Biophysical Research Communications 232, 822-826.

Zhang Y, Proenca R, Maffei M, Barone M, Leopold L \& Friedman JM (1994) Positional cloning of the mouse obese gene and its human homologue. Nature 372, 425-432. 